\title{
The Rustler Springs Sulphur Deposits As A Source of Fertilizer
}

\author{
By \\ GLEN L. EVANS
}

Report of Investigations-No. 1

BUREAU OF ECONOMIC GEOLOGY

The University of Texas

Austin 12, Texas

September, 1946 


\title{
The Rustler Springs Sulphur Deposits As A Source of Fertilizer
}

\author{
By \\ GLEN L. EVANS
}

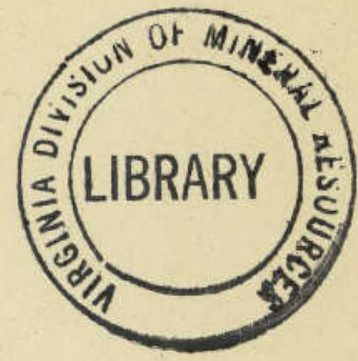

Report of Investigations-No. 1

BUREAU OF ECONOMIC GEOLOGY

The University of Texas

Austin 12, Texas

September, 1946 


\section{CONTENTS}

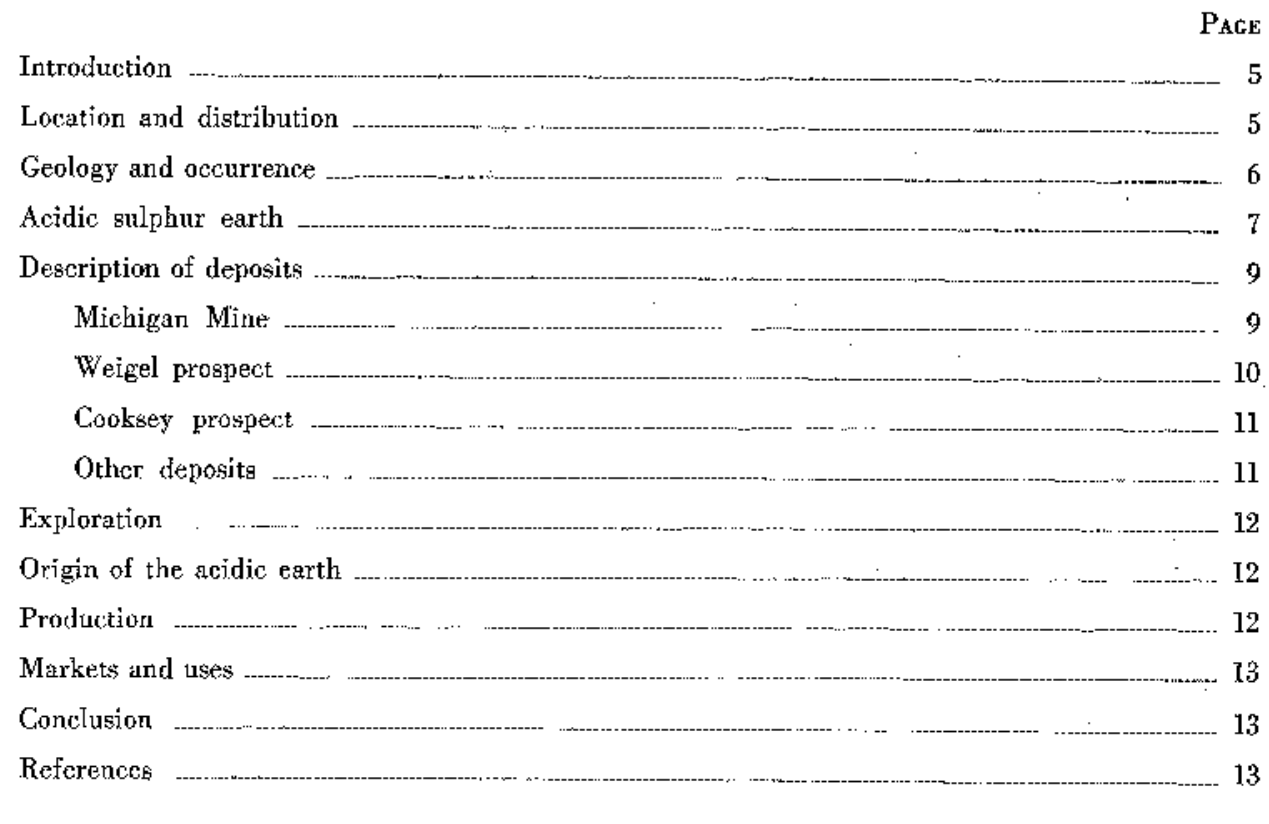

\section{ILLUSTRATIONS}

\section{FIGURES}

1. Map showing location of Rustler Springs district

2. Geologic map of the Rustler Springs district, Culberson and Reeves counties, Texas.

Facing p. 8

3. Section exposed on south wall of trench on Weigel prospect, Culberson County, Texas. 10 
1

1!:

!!

: 


\title{
THE RUSTLER SPRINGS SULPHUR DEPOSITS AS A SOURCE OF FERTILIZER
}

\author{
GLEN L. Evans
}

\section{INTRODUCTION}

The occurrence of sulphur in the vicinity of Rustler Springs in northeastern Culberson County, Texas, has been known since 1854 when, according to Phillips (1902, pp. 13, 71), the mineral was recognized by William P. Blake, a geologist attached to a U. S. War Department expedition making a survey of a railroad route from the Mississippi River to the Pacific Ocean. In the latter part of the 19th century and first part of the 20th century the Rustler Springs district was regarded as a favorable potential source for domestic supplies of native sulphur. Studies of the deposits were made by geologists of State and Federal agencies, resulting in several published reports (Smith, 1896; Richardson, 1904, 1905; Porch, 1917; Baker, 1934), and prospecting by private interests resulted in the discovery of additional deposits and substantially enlarged the area in which sulphur is known to occur. Attempts were made to mine and extract the sulphur on a commercial basis, but these efforts resulted in the production of only small amounts of refined sulphur. Interest and activity in the district gradually declined as a result of the development and exploitation of the cap rock sulphur deposits of salt domes in the Texas and Louisiana coastal region which, because of their enormous size and favorable location, soon became the world's most important source of sulphur.

During the past few years, however, the Rustler Springs deposits have attracted attention as a source of mineral fertilizer rather than native sulphur. One operator, Mr. P. L. Meath of Houston, Texas, since 1940 has been producing and marketing as fertilizer an acidic earthy material which occurs in association with some of the sulphur deposits. The apparent acceptance and growing demand for the acidic earth as a fertilizer and soil conditioner in at least one important agricultural area, the lower Rio Grande Valley citrus and vegetable district of south Texas, together with the fact that the material is known to contain ingredients beneficial to certain types of soils, indicates that the Rustler Springs sulphur deposits may have considerable importance as a source of mineral fertilizer and soil conditioner.

The purpose of the present report is to review briefly the geology of the Rustler Springs district, describe the occurrence of some of the acidic sulphur earth deposits, insofar as that is possible at their present state of exposure, and discuss some of the economic aspects involved in production of mineral fertilizer from these deposits. The report is based upon a review of the available literature and short field examinations made by the writer during 1942, 1943, and 1946 and should be regarded as a progress report.

\section{LOCATION AND DISTRIBUTION}

The Rustler Springs sulphur district, as here considered, is a rectangular area roughly 40 miles long in a north-south direction and 30 miles wide, including part of northeastern Culberson County and the adjacent northwestern part of Reeves County. (See fig. 1.) The district centers near Rustler Springs, which is 34 miles northwest of Toyah and about 50 miles west of Pecos. The boundaries of the district are somewhat arbitrarily placed to include most or all of the known surface occurrences constituting a closely related group of deposits. Underground occurrences of sulphur found in well borings have been reported (Baker, 1934, pp, 613-616) from outside the district in west Texas, and surface deposits are known to the north in New Mexico, but a consideration of these outlying occurrences is not within the scope of this investigation.

The district can be entered over graded dirt roads from Toyah, a town on U. S. highway No. 80 and the Texas and Pacifie Railroad, or from Orla on the Panhandle and Santa Fe Railroad and U. S. highway No. 285. Many of the prospects can be approached only on ungraded ranch roads and trails which become temporarily impassable during wet weather. The area is sparsely settled and generally devoid of 


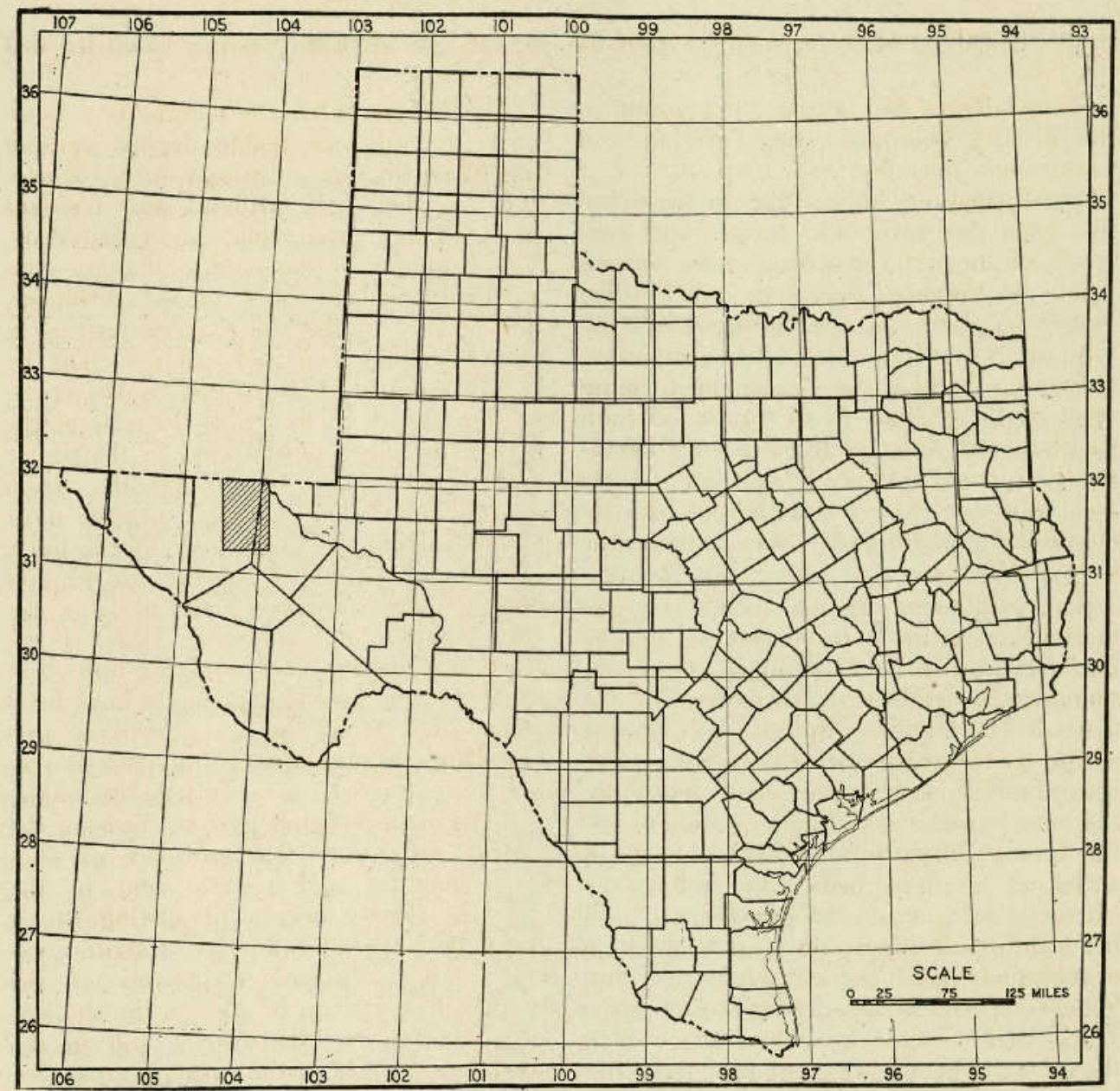

Fig. 1. Map showing location of Rustler Springs district.

prominent land or survey markers. Employment of local guide service is advisable in attempting to reach any but the better known localities.

Most of the known sulphur is in the northern part of the Rustler Springs district within school blocks Nos. 42, 109, $110,111,113,114$, and 115 and in blocks 60 and 61 of township 2, Culberson County. Elsewhere in the district, and particularly in the southern part, the deposits are widely spaced. The seeming concentration of sulphur in the northern part may be due to more favorable exposures in that area and to intensified prospecting in the vicinity of some of the old workings rather than to the actual number and size of deposits which may be present.

\section{GEOLOGY AND OCCURRENCE}

The Rustler Springs sulphur deposits lie within the outcrop area of the Permian Castile formation along the western flank of the Delaware synclinal basin. Physiographically the region is a broad, eastward-sloping, aggradational plain now in an early stage of dissection by tributary arroyos of Pecos River. The general flatness of the area is interrupted by occasional low ridges or buttes, by subsidence depressions of various sizes, and by an irregular belt of low hills, known as the Rustler Hills, which extends in a north- 
south direction across the central part of the plain.

The bed rock formations outcropping in the district belong to the Permian and Cretaceous periods (see map, fig. 2). ${ }^{1}$ These formations have a general eastward dip into the Delaware basin, but over much of the outcrop area the normal attitude of the beds has been greatly disturbed by slumping due to extensive solution of gypsum in the Castile formation. Overlying the bed rock strata, and forming most of the surface of the plain on both east and west sides of the Rustler Hills, is a widespread mantle deposit of gypsite and alluvium which apparently has accumulated at different times during the Cenozoic.

The sulphur occurs in the Castile formation and in the gypsite-alluvium mantle but has not been found in significant quantities in the other formations of the district. The acidic sulphur earth, so far as the writer's observations are concerned, is confined to near-surface deposits within the mantle materials. In its exposed facies the Castile formation consists of a thick series of gypsum beds. The effects of extensive solution of the gypsum are seen in widespread slumping and sink hole development and in the cavernous and honeycombed character of exposed beds. The Castile formation is best exposed in the western part of its outcrop area, but local exposures are found around the base of the Rustler Hills, along the creeks and arroyos crossing the gypsite plain, and in the sides of more recent sinks.

Sulphur, where it occurs in any considerable quantity within the Castile formation, is found in solution openings and cracks and is usually associated with secondary selenite, hydrogen sulphide gas, and black, clayey carbonaceous material. The sulphur is present as disseminated particles or crystals or in massive bodies. According to Porch (1917, p. 59), the sulphur occurrences within the unaltered massive gypsum appear to be of little consequence, and the writer's recent ob-

\footnotetext{
${ }^{1}$ For a more complete deseription of the several stratigraphic units outoropping in the Rustler Spring district see Univ. Texas Bull. 3232, section on pre-Paleozoic and Paleozoic systems in Texas, by E. H. Sellards, and section on Mesozoic systems, by W. S. Adkins. The Delsware synclinal basin, or the Toyah basin, and related structural features are described in Univ. Texas Bull 3401 structural struelural geology of Trans.Pecos Texas, by C. L. Baker.
}

servations of core testing confirm this conclusion.

The gypsite-alluvium mantle is a compact to semi-consolidated deposit consisting of earthy, secondary gypsum, or gypsite, together with alluvial and residual gravels, sand, and some clayey materials. The thickness of the mantle changes considerably within short lateral distances, due largely to the sharp irregularities in the underlying bed rock surface. The irregular contact is illustrated by the crosssection shown in figure 3 . In general the gypsite is most concentrated in the upper and thinner parts of the mantle, while gravel and other clastics appear most abundantly in the lower and thicker parts of the deposit. Most of the gravel and boulders are reworked material from the conglomerate and limestone beds of the Rustler formation and overlying units, but some igneous pebbles appear to have been transported from the comparatively distant Davis Mountains. The gypsite is secondarily derived, as a caliche-like material, from underlying gypsum beds in the Castile formation. The presence of scattered pebbles and coarse sand in the gypsite usually serves to distinguish it from partially decomposed Castile gypsum still in place. Exposures of the mantle deposits can be seen in the shallow arroyos crossing the district and in the workings of most of the sulphur prospects.

Most of the sulphur and perhaps all of the acidic sulphur earth associated with some of the sulphur occurrences which have been exposed by prospect workings in the Rustler Springs district occur in the gypsite-alluvium mantle. It does not necessarily follow, however, that the mantle materials are the most prolific or favorable host strata for sulphur, as many of the shallow workings do not penetrate deeply enough to expose the bed rock adequately, and there are not enough core drill data available to warrant such a conclusion. The acidic earth, however, appears to be a near-surface development confined essentially to the mantle materials.

\section{ACIDIC SULPHUR EARTH}

The acidic sulphur earth originates in near-surface levels at favorable localities 
in the mantle deposits. The material commonly is soft and porous and may be gray, brown, or almost black in color. The acidic earth consists of a mixture of calcium sulphate in both earthy and crystalline forms, siliceous materials in the form of sand grains and gravel, sulphuric acid, sulphur, clay minerals, carbonaceous matter, and small amounts of compounds of iron, sodium, and potassium. The proportions of the several constituents differ markedly in different parts of any given deposit. In general, the sulphur-rich parts of a deposit contain relatively small proportions of calcium sulphate, which suggests replacement of the gypsum by sulphur.

The chemical composition of sulphurbearing earth from different localities is shown in the following tables of analyses. Table 1 is reproduced from Porch (1917, p. 61). The percentage of sulphuric acid present in these samples was not separately determined but is included in the percentages shown for sulphur trioxide and moisture. Ferrous and aluminum sulphates, which may have been present in small quantities and which may be regarded as acidic compounds, would be included in the percentages shown for sul- phur trioxide, ferric oxide, and alumina. The gypsum, or calcium-sulphate, content is given in the percentages shown for lime and sulphur trioxide.

The analyses given in Table 2, made by R. M. Wheeler of the Bureau of Economic Geology, are for major constituents of three samples of partially oxidized sulphur ore from acidic sulphur earth deposits, and of one sample of sulphurbearing gypsum from a core taken in the Castile gypsum included here for comparison.

Table 2. Analyses of samples of acidic sulphur earth. R. M. Wheeler, analyst.

\begin{tabular}{lrrrr} 
& (a) & \multicolumn{1}{c}{ (b) } & (c) & (d) \\
Free $\mathrm{H}_{2} \mathrm{O}$ & 3.56 & 11.40 & 4.90 & 13.62 \\
Ignition loss & 59.46 & 36.06 & 53.20 & 9.64 \\
$\mathrm{SiO}_{3}$ & 28.88 & 35.80 & 33.58 & 2.72 \\
$\mathrm{R}_{2} \mathrm{O}_{3}$ & 0.98 & 0.90 & 1.44 & 0.40 \\
$\mathrm{CaO}_{\mathrm{SO}}$ & 0.60 & 10.44 & 3.70 & 30.30 \\
$\mathrm{SO}_{3}$ as sulfate & & & & 42.08
\end{tabular}

(a) Sample selected from near the west end of the trench on the Weigel prospect illustrated in figure 3. The sample is from an oxidizing, massive sulphur body; it is considerably richer in sulphur and lower in gypsum content than the surrounding acidic earth.

(b) Sample taken from the Michigan mine near the mouth of an old shaft in the northeastern corner of the main open pit. Part of the

Table 1. Mineral analyses of sulphur-bearing deposits from the Rustler Springs sulphur field.

J. E. Stullken, analyst.

$\begin{array}{lr} & \text { (a) } \\ \text { Silica } & 2.34 \\ \text { Ferric oxide } & 0.15 \\ \text { Alumina } & 1.95 \\ \text { Titanic oxide } & 31.72 \\ \text { Phosphorus pentoxide } & 0.36 \\ \text { Lime } & 28.87 \\ \text { Magnesia } & 3.16 \\ \text { Sulphur trioxide } & 4.89 \\ \text { Sulphur, free } & 0.08 \\ \text { Sodium oxide } & 10.10 \\ \text { Potassium oxide } & 16.04 \\ \text { Moisture } & \\ \text { Loss on ignition } & 99.66\end{array}$

Bauxite present

(a) Drab-colored porous rock containing much selenite. From the center of section 34 , block 70. Sample taken by Dr. J. A. Udden.

(b) Pure white clay-like material containing considerable gypsum. From the southeast corner of section 13, block 70 . Sample taken by Dr. J. A. Udden.

(c) Clay from the southeast corner of section 13, block 70. Sample taken by J. A. Martin, Jr., Toyah, Texas.

\begin{tabular}{|c|c|c|c|c|}
\hline (b) & (c) & (d) & (e) & (f) \\
\hline 10.66 & 34.54 & 37.20 & 8.60 & 49.34 \\
\hline 0.08 & 11.44 & 0.27 & 0.32 & 0.16 \\
\hline 33.48 & $\begin{array}{r}16.69 \\
6.67\end{array}$ & 1.63 & 11.28 & 0.18 \\
\hline & Trace & Trace & & \\
\hline 2.50 & 6.76 & 19.76 & 5.72 & 1.35 \\
\hline 0.34 & 1.01 & 0.51 & 0.30 & 0.32 \\
\hline & 5.08 & 30.59 & 19.23 & \\
\hline 13.35 & 1.70 & 1.00 & 22.00 & 46.00 \\
\hline 6.14 & 0.70 & 0.34 & 1.24 & \\
\hline 0.19 & 1.16 & 0.34 & 1.32 & \\
\hline 2.00 & 9.28 & 7.64 & 10.06 & 2.30 \\
\hline 31.25 & 10.50 & 1.40 & 20.14 & 0.86 \\
\hline 99.99 & 99.53 & 100.68 & 100.21 & 100.51 \\
\hline 42.23 & & None & & None \\
\hline
\end{tabular}

(d) Siliceous gypsite. Typical rock from the Johnson prospect.

(e) Dark gypsiferous and conglomeratic material from beneath the hard conglomerate layer on the north side of locality marked 8 on the sketch map of the Michigan Sulphur and Oil Company property [map in Porch, 1917].

(f) Typical brown earthy material from the main exposure at the Cooksey prospect. 


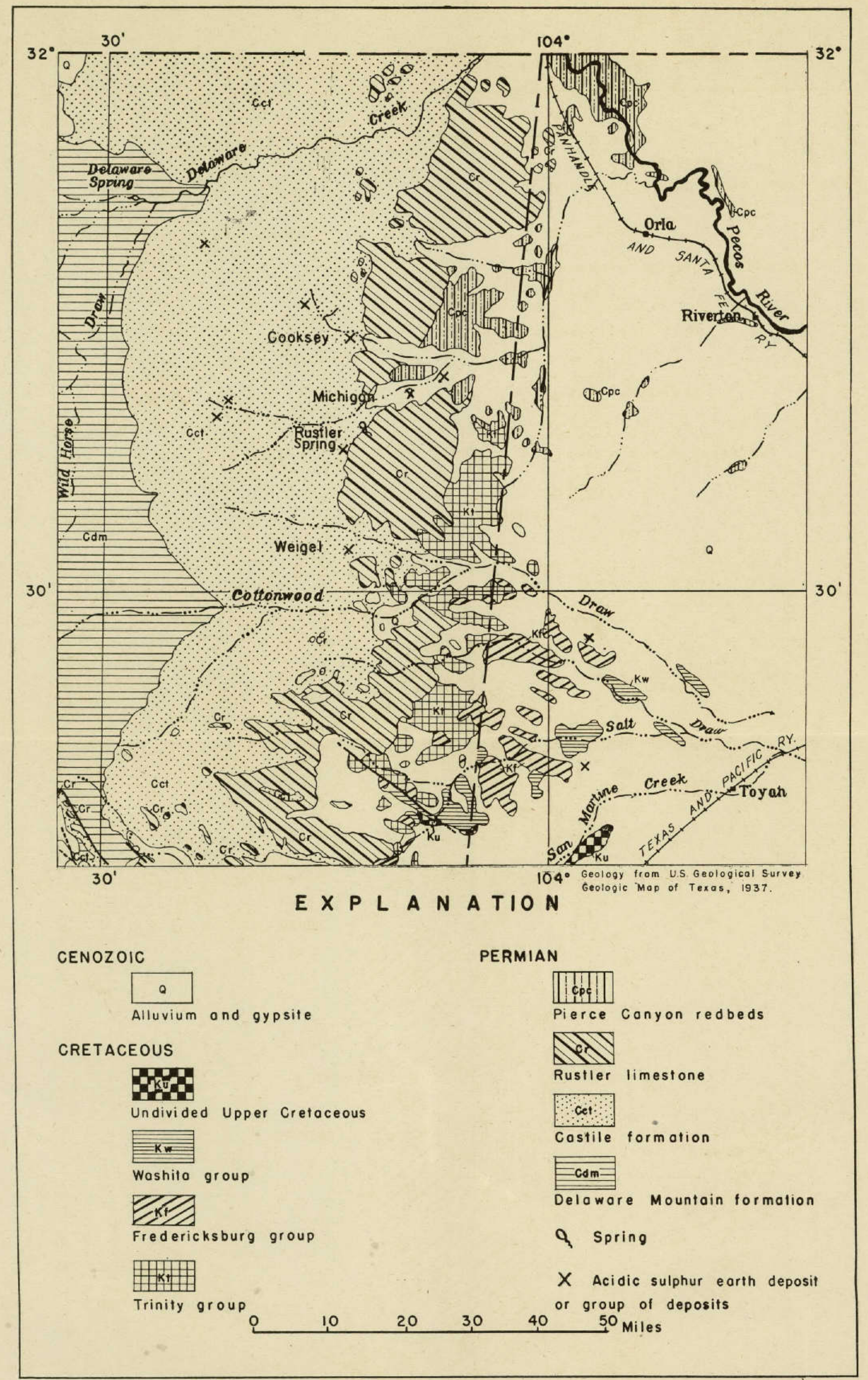

Fig. 2. Geologic map of the Rustler Springs district, Sulberson and Reeves counties, Texas. 

sulphur in this sample is in the form of yellowish-green crystals which partially fill small cavities in the earth.

(c) Sample is from a partially oxidized sul. phur body in the main workings of the old Cooksey prospect.

(d) Sample is a core from a depth of 42 feet on the Weigel prospect. The sample is massive Castile gypsum containing solution cavities partially filled with yellow sulphur.

In Table 2 the percentages listed under free $\mathrm{H}_{2} \mathrm{O}$ represent loss of water at drying temperature $\left(105^{\circ}\right.$ C. $)$. This may also include minor amounts of other constituents volatilizing at low temperatures, as a sulphurous odor could be detected during the drying operation. Ignition loss percentages include essentially all of the free sulphur present and probably include some volatile carbonaceous material as well as some combined water. $\mathrm{R}_{2} \mathrm{O}_{3}$ percentages include alumina and iron oxides not separately determined. $\mathrm{CaO}$, or lime, percentages are essentially all derived from the $\mathrm{CaSO}_{4}$ present in the form of gypsite and gypsum.

The acid content of the four samples shown in Table 2 is indicated by a leaching test, the results of which are summarized in Table 3 . The samples were leached in distilled water at room temperature for 18 hours, 40 parts by weight of water being used for each part of acidic sulphur earth ( 5 grams of acidic earth in 200 cubic centimeters of water). The liquid was then filtered off each sample and its acidity determined by a Beckman $\mathrm{pH}$ meter. The considerable acidity in the three acidic sulphur earth samples(a), (b), and (c) - is shown by their relatively low $\mathrm{pH}$ values, while the slight acidity of sample (d), the sulphur-bearing gypsum taken from the Castile formation, is indicated by a high $\mathrm{pH}$ value. The silica and iron oxides percentages were determined from the dried residue of samples after water-soluble constituents had been removed by leaching.

Table 3. Results of leaching test.

\begin{tabular}{lcrrl} 
& (a) & \multicolumn{1}{c}{ (b) } & \multicolumn{1}{c}{ (c) } & (d) \\
$\mathrm{SiO}_{2}$ & 30.56 & 31.19 & 27.33 & 2.40 \\
$\mathrm{Fe}_{2} \mathrm{O}_{3}$ & 0.011 & 0.11 & 0.05 & 0.19 \\
$\mathrm{SO}_{3}$ (soluble) & 12.11 & 6.08 & 2.27 & 3.54 \\
$\mathrm{pH}$ & 1.45 & 1.90 & 2.15 & 5.80
\end{tabular}

Samples (a), (b), (c), (d) are the same as those described in Table 2.

\section{DESCRIPTION OF DEPOSITS}

There are few, if any, good natural exposures of sections through the acidic earth deposits in the Rustler Springs district. Most of the deposits occur at nearsurface levels in flat or gently sloping areas where there has been very little denudation by erosion for a comparatively long period of time. Examination of the deposits at the present time must be confined to the limited exposures in old prospect workings, many of which are now caved and partly filled; hence it is not now possible to ascertain the full thickness and areal dimensions of any of the deposits. The localities described below may be considered representative of the area.

Michigan Mine.-This deposit, formerly worked to some extent for sulphur and now worked for acidic sulphur earth, is located about 18.5 miles southwest of Orla, Texas, on section 16, school block 111, Culberson County. The locality lies near Salt Draw and near the eastern edge of the Rustler Hills. The part of the deposit exposed in open cuts and shallow shafts covers an area of about 4 acres within a shallow, flat-bottomed natural surface depression having an area of 10 or 12 acres. The depression originally may have been formed by subsidence, but obviously it has been deepened to some extent by deflationary action of the wind. The floor of the depression is on a bed of light gray gypsite from 2 to 4 feet in thickness which effectively conceals the underlying sulphur and acidic earth except where exposed by trenches.

The walls of open cuts and shafts expose sections of gypsiferous, sulphur-bearing acidic earth 6 to about 25 feet thick beneath the capping of gypsite. According to Porch $(1917$, p. 38), a shaft, now partially filled, near the north end of the depressed area originally was 46 feet deep and was in sulphur-bearing dark earth and some gravel to the bottom. Much of the exposed material is soft and porous but sufficiently coherent to stand fairly well in vertical cuts.

Sulphur occurs to some extent throughout most of the exposed material. A few localized masses of high-grade massive sulphur are present in an open cut near 
the south end of the workings, and irregular veinlets up to 2 inches wide of nearly pure sulphur are exposed in the walls of the shaft at the north end. The average sulphur content, however, probably would not exceed 10 to 15 per cent. Sulphuric acid is discernible to the taste in nearly all parts of the exposed material. The strongest acid concentrations seem to be localized around the sulphurrich portions of the deposit and within the dark brown and black earths in which only small amounts of free sulphur are apparent. Lighter colored phases of the deposits containing a low percentage of sulphur also are usually relatively weak in acid content. Limestone pebbles now altered to gypsum can be seen at several places in the old workings. Secondary selenite crystals within the earth, which have been deeply etched and locally altered to a white powdery material, also show the effects of alteration presumably due to the action of free acid.

The reserves of acidic sulphur earth at the Michigan Mine, while evidently quite large, cannot be accurately estimated until the average thickness and areal extent have been established in additional test pits.

Weigel prospect.-The Weigel prospect consists of several adjoining claims situated in section 17, school block 54, Culberson County, approximately 30 miles by road northwest of Toyah. The locality is on a gently sloping part of the gypsite plain and is partially encircled by low, limestone-capped hills from 1 to 2 miles east of the main Rustler Hills.

The occurrence of sulphur was discovered in a small barren area depressed about 3 feet below the level of the surrounding plain. Several closely grouped small prospect pits and trenches were dug some years ago in the vicinity of the exposure, and exploration by core drilling has recently been carried on by the present owner, Mr. B. F. Weigel. The best exposure of acidic sulphur earth is in the west end of a trench 5 feet deep and 100 feet long, a wall section of which is illustrated in figure 3 . The top of the acidic earth rises in one place to within a few inches of the land surface, while the base is nowhere exposed. Cuttings

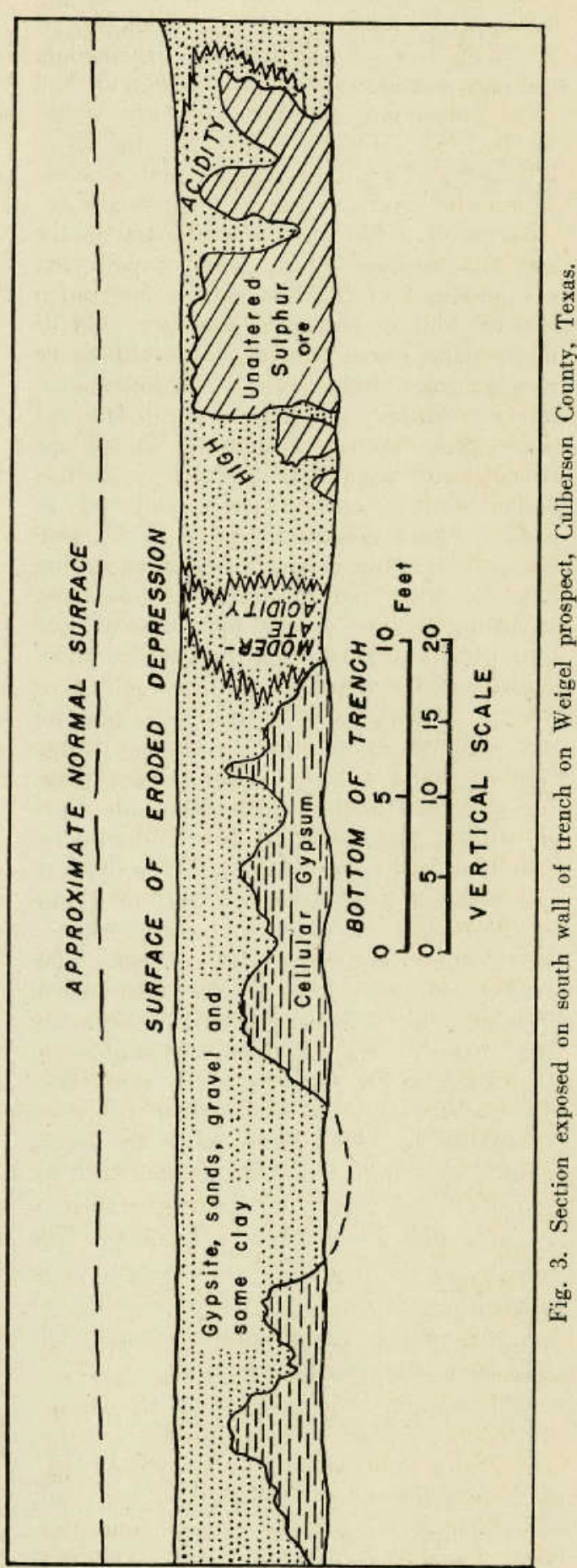


from a ncar-by drill test, however, indicate'that the mantle materials containing some sulphur locally reach a thickness of 20 to 25 feet. As secn in the illustration, the exposed lateral extent of the acid- and sulphur-bearing materials is only about 40 feet, the deposit grading outward to the east and west into the normal gypsitealluvium mantle. Two other small exposures of sulphur and acidic earth are seen in shallow pits located respectively 100 lcet east of the east end of the trench and 60 feet southwest of the west end of the trench. Two other pits a short distance west of the Iatter exposure do not reveal cilher sulphur or acidic earth. One of these pits exposes massive gypsum, ap. parently of the Castile formation, within 4. feet of the plain surface.

The deposit consists partly of massive high-grade sulphur rock of pale yellow to metallic gray color, which encloses the siliceous pebloles of the mantle materials but contains very little gypsum; dark brown clayey materials of bigh acid content and containing scattered lumps of frec sulphur lying next to the oxidizing sulphur masses; and a mixture of gypsite and siliceous pcbbles with small amounts of sulphur and relatively low acid content which form the outer fringe of the deposit and which grade oulward to normal mantie materials.

The small amount of test pitting done to dato on the Weigel prospect indicates that the acidic sulphur earth occurs in local deposits or concentrations separated. by harren areas in the matitle materials and by upward protruding blocks of Castile gypsum. The amount of work, however, has been entirely inadequate to demonstrate the number and size of individual deposits which may be present within the area.

Recently core drilling carried on for the purpose of testing possible sulphur bodies in the deeper lying Castilc gypsum as weli as at shallow horizons, has revealed sulphur-bearing gypsum to depths of 70 feet or more. The sulphur from the Castile docs not appear to have been ap. preciably altered by oxidation, and no acid taste is discernible even in samplos taken by dry coring. Ten tests ranging from 22 to 73 feet in depth were drilled within a rectangular area 330 feet long and 200 feet wide surrounding the prin. cipal trench exposure. A considerable amount of sulphur was encountered within porous and cavernous Castile gypsum in 5 of these tests at depths between 12 and 70 fect. The actual percentage of sulphur present, however, could not be determined due to very poor core recovery, loss of cultirngs and drilling fiuid in caverns, and to the tendency of sulphur cuttings to hreak into fine particles and form a sludge with drilling mud. The superficial sulphur from which the acidic earth is derived presumably is related genclically to the underlying occurrences in the Castile gypsum.

Cooksey prospect.-Acidic earth with some masses of high-grade sulphur rock similar to that of the Weigel prospect occurs at the Cooksey prospect 25 miles wcot of Orla and near the lime between sections 10 and 15 on school block 114, Culberson County. Thie deposit lies on a gentle slope and is exposed in an old pit now about 7 feet deep, 80 fect wide, and 170 feet long. The acidic earth is covered by a gypsite layer 2 to 4 feet thick. As in other localities, the sulphur and acid content of the exposed material is irregularly distributed but appears to be greatest in the deeper parts of the exposed section. The thickness and areal extent of this deposit are unknown.

Other deposits.-There is an occurrence of acidic sulphur earth 0.7 milc west of the old Walker ranch headquarters on scction 4, school block 109, Culberson County. The material is exposed in two small test pits each aboul 5 feet deep located about 200 feet apart: Acidic earth is also present al the Kyle prospect on section 18, school block 45 . The material probably is associated to some exlent with all or nearly all of the shallow sulphur occurrences found in the superficial gypsile-alluvium deposits in the district, many of which have not been examined by the writer. Following is a list of the localities from which sulphur has been reported by Porch:

\footnotetext{
Culberson Cotrnty

Fownship 1, block 62, section 18

Township 2, block 60; sections 15, 16, 44

Tuwnship 2, hlock 61, sectiuns $8,16,17,18$

School bluck 42, sectians 7, 8, 9, 10

School block 54, section 18 '
} 
School black 109, sections 4, 5, 8, 9, 10, 15, $24,26,28$

School block 111, sections 2 or $3,9,10,11$, $13,14,16$

School block I13, sections. 13, 14

School block 115 , sections $7,10,11,18,19$, 22, 23

Reeves County

Block 70, sections 13,34

Schaol. block 59, sections 8, 18

\section{EXPLORATION}

The acidic sulphur earth deposits with few exccplions are poorly exposed but arc usually discovered from small, inconspicuous outcrops in areas of recent shallow erosion in the gypsite-alluvium mantle. The plain surface normally is covered by a crust 1 to 6 feet thick of partially indurated gypsite and soil which overlies and conceals the horizon in which acidic sulphur earth isually occurs. It is desirable to find Iocalities from which the surface crust has been eroded away, leaving the main body of the gypsite-alluvium mantle exposed. The most promising places in which to prospect for new deposits are the wind-scoured depressions on the gypsite plain and along slopes of divides and valley margins where gully erosion has cut through the surface crust.

The outcrop of acidic earth may be recognized by its dark gray, brown, or black color, by the odor of hydrogen sulphide, and by its sharp acid taste. Pebbles of native sulphar associated with the acidic earth also may be present on the weathered surface. The sulphur pebbles tend to develop a gray surface film on weathering and are not easily recognized until broken.

Determination of the dimensions and character of an acidic earth deposit probably can best be done by means of test pitting and trenching. Post hole augers or similar devices which can be used for drilling without water or drilling mud might prove useful in testing softer phases of a deposit. Testing with standard core drilling equipment at the Weigel prospect did not prove very satisfactory, as the acidic earth was too incoherent for good core recovery, and samples were contaminated from mixing with drilling fluid. It is probable that similar difficulties would be encountered at other localities in the district.

\section{ORIGIN OF THE ACIDIC EARTH}

T'he sulphuric acid of the acidic earth deposits is evidently a product of oxida. tion of sulphur formed at shallow depths below the present land surface. The several occurrences of the acidic earth in poorly drained flatlands and within slight depressions suggest that temporarily impoinded waters forming damp zones in the mantle materials may have influenced the formation of acid. The original deposition of free sulphur in the mantle materials secms to have been controlled by surface conditions rather than by the character or structural conditions of the under. lying béd rock. Porch (p. 62) has suggested that the sulphur may have been deposited by oxidation of hydrogen sulphide gas and points out that hydrogen sulphide is encountered all over the Rustler Springs district.

\section{PRODUCTION}

The only producer of acidic sulphur earth now active in the Rustler Springs district is the Pecos-Orla Sulphur Com. pany, of which Mr. P. L. Meath of Houston is president and general manager. The material now being produced comes from the old workings of the Michigan Sulphur and Oil Company, now known as the Michigan Mine, located 18.5 miles by road southwest of Orla, Texas. Formerly a small amount of the acidic earth was taken from other o]d sulphur workings localed near the Michigan properties.

Mining consists simply of loading by hand melhods from selected spots on the floor and walls of the old open pit, the sterile overburden having been stripped away during earlier operations when an attempt was made to mine and extract native sulphur from richer portions of the deposit. The material is hauled by trucks over a graded dirt road to the processing plant in Orla, where stock piles of the different grades of material being produced are maintained.

Processing of the acidic earth for marketing consists of grinding in a 20 -inch hammer mill and screening through a nine-sixieenths-inch mesh screen. The material thus prepared ranges from small lumps to dust-size particles, therc being no loss of fines or other waste products 
in the operation. In the process of grinding, the different grades of material are mixcd together in an effort to obtain a fairly uniform quality in the ground product. Grading is done on the basis of phys. ical appearance only, and no laboratory control of acid, sulphur, and other con. stituents is maintained. Consequently, probably there is a considerable variation in percentage composition of the finished product. The ground earth is loaded in bulk by a mechanical loader into box cars for shipment.

Production was begun in 1940 on a very small scale, due to lack of any but experimental markets, and for the first two years a total of only a few hundred tons was produced. Tncreased market demands, however, have considerably enlarged the production rate so that approximately 7500 tons have heen produced during the past two and one-half years.

\section{MARKETS AND USES}

Most of the production of acidic sulphur earth has been marketed in the lower Rio Grande Valley agricultural district, 'only minor amounts having been sold in other areas. The material is used as a fertilizer and soil conditioner on both vegetable and citrus lands. Some users report favorable results from application of about one ton of acidic earth per acre on vegetable land and about 30 pounds per tree on citrus groves, the application being renewed at two-year intervals.

\section{CONCLUSION}

The acidic earth deposits occurring associated with sulphur in gypsite-alluvium superficial deposits in the Rustler Springs district appear to have considerable value as a fertilizer and suil conditioner on highly alkaline soils. However, a comparison of the relative value of the acidic sulphur earth with other mineral fertilizers as to effcctiveness, costs, and convenience of application must be made by soil scientists and by users of the material.

The numerous deposils, now only partially exposed, indicate that large ton. nages of acidic sulphur earth could be developed by systematic prospecting, and mining costs should be comparatively low as much of the matorial now exposed would require very little stripping for open-pit mining. Many detailed data relative to the acidic earth are still lacking and can be supplied only by further field and Iaboratory studies and by thorough trials on different soils and crops.

\section{REFERENCES}

Following is a partial list of the literature dealing with the Rusller Springs sulphur deprosits. Unforlunatcly most of these publications are out of print.

Bakfr, C. L., Sulphur, in The Geology of T'exas, Vol. II: Univ. Texas Bull. 3401, pp. 613-618, 1934 [1935].

PH.ILEIPs, W, B., Report of progress for 1901Sulphur, oil and quicksilver in Trans-Pecos Texas: Univ. Texas Bull. 9 (Min. Surv. Ser. Bul1. 2), 43 pp., 1902 .

Poncн, E. L., JR, The Rustler Springs sulphur deposits: Univ. Texas Bull, 1722, 71 pp. 1.917.

RTCHARDSON, G. B., Report of a reconngibsance in Trans-Pecos Texas north of the Texas and Pacific Railway: Univ. Texas Btıll. 23. (Min. Surv. Ser. Bull. 9), pp, 68-71, 1904.

-.. Native sulphur in EI Paso Counly, Texás: U. S. Geol. Surv. BulI. 260, pp. 589-592, 1905.

SmIth, E. A., Notes on nalive sulphor in Texas: Science n.s., vol. 3 , pp. $657-659,1896$. 
